\title{
The Team Production Model as a Paradigm
}

\author{
Brian R. Cheffins*
}

\begin{abstract}
This paper forms part of the proceedings for the $6^{\text {th }}$ Annual Berle Symposium (2014), which focused on Margaret Blair and Lynn Stout's 1999 Virginia Law Review article "A Team Production Theory of Corporate Law" (available at http://ssrn.com/abstract=425500). Blair and Stout suggested a few years after the publication of their 1999 article that their team production model was poised to emerge as part of a new corporate law "paradigm" in the sense that Thomas Kuhn deployed the term in his widely cited The Structure of Scientific Revolutions. This paper revisits Blair and Stout's team production theory by offering a critique of this claim and in so doing draws upon key corporate law theories and trends to offer insights concerning their model.
\end{abstract}

Keywords: team production; corporate law theory; managerialism; shareholder primacy; nexus of contracts; shareholder activism; hedge funds

JEL Codes: G34, K22, L21

(July 2014 draft)

S.J. Berwin Professor of Corporate Law, Faculty of Law, University of Cambridge. 


\section{INTRODUCTION}

Margaret Blair and Lynn Stout introduced the team production theory of corporate law in a landmark 1999 article in the Virginia Law Review. ${ }^{1}$ Their team production model, as is well-known, characterized the board of directors as a mediating hierarchy that balances the interests of a corporation's various constituencies and does so in a way that successfully addresses in the context of the publicly traded corporation the challenges associated with fostering productive activity requiring combined investment and coordinated effort. ${ }^{2}$ According to Blair and Stout, their team production theory was an analytical step forward as compared to the influential contractarian model of the corporation oriented around "agency costs" with managers as agents and shareholders as principals. ${ }^{3}$ Additionally, they said their model explicitly challenged a dominant shareholder primacy "norm". ${ }^{4}$ Blair and Stout suggested subsequently in a 2006 article that the team production model not only could explain a wide range of important phenomena in the business world but potentially provided the basis for a new corporate law paradigm, a claim Stout reiterated in her 2012 book The Shareholder Value Myth. ${ }^{5}$

Blair and Stout's team production model has attracted widespread interest and clearly is an appropriate departure point for a conference such as the $6^{\text {th }}$ Annual Berle Symposium. Justice John Paul Stevens cited their 1999 article in his widely read dissenting opinion in

1 Margaret M. Blair and Lynn A. Stout, A Team Production Theory of Corporate Law, 85 VA. L. REV. 247 (1999).

$2 \quad I b i d ., 253,271-72,275-86,298-305$; Margaret M. Blair and Lynn A. Stout, Director Accountability and the Mediating Role of the Corporate Board, 79 WASH. U.L.Q. 403, 41922 (2001).

3 Blair and Stout, supra note 1, 248-50, 254-55.

$4 \quad$ Ibid., 249, 253.

5 Margaret M. Blair and Lynn A. Stout, Specific Investment: Explaining Anomalies in Corporate Law, 31 J. CORP. L. 719, 723, 733-37 (2006); LYNN STOUT, THE SHAREHOLDER VAlue Myth: How PutTing Shareholders First HaRMS InVESTORS, CORPORATIONS, AND THE PUBLIC 58, 85 (2012). See further infra notes 19 to 21 and related discussion. 
Citizens United v Federal Election Commission. ${ }^{6}$ Moreover, as of 2012, no other legal article published in 1999 has been cited more often. ${ }^{7}$ Nevertheless, while Blair and Stout's work on team production constitutes a logical and indeed admirable choice as the topic for the $6^{\text {th }}$ Berle Symposium, their invocation of "paradigm" rhetoric to characterize the team production model's place in the corporate law theory firmament is problematic.

According to the Oxford English Dictionary, a paradigm can be defined as "a generally accepted world view."8 Blair and Stout have not employed "paradigm" in this generic sense when seeking to situate the team production model. Instead, they have specifically referenced Thomas Kuhn's The Structure of Scientific Revolutions. ${ }^{9}$ In this widely cited book Kuhn deployed the term "paradigm" in order to characterize scientific endeavour in a manner different from the orthodox view that there is accumulation of knowledge by reliance on "scientific method". 10

Blair and Stout's 2006 invocation of Kuhn's analytical framework was not entirely a novel one. Instead, other corporate law scholars, including myself, had previously drawn

$6 \quad$ Citizens United v Federal Election Commission 130 US 876, 978 (2010); http://law.vanderbilt.edu/news/research-by-margaret-blair-cited-in-citizens-united-dissent/ (accessed April 24, 2014).

$7 \quad$ Fred R. Shapiro and Michelle Pearse, The Most Cited Law Review Articles of All Time, 110 Mich. L. REV. 1483, 1495 (2012). The search methodology extended beyond law reviews to encompass other academic journals - ibid., 1486-87.

$8 \quad$ http://www.oed.com/view/Entry/137329?redirectedFrom=paradigm\#eid (accessed April 24, 2014).

$9 \quad$ Blair and Stout, supra note 5, 721-22; STOUT, supra note 5, 58; Lynn A. Stout, On the Rise of Shareholder Primacy, Signs of Its Fall, and the Return of Managerialism (in the Closet), 36 Seattle Univ. L. ReV. 1169, 1181, n. 65, discussing Thomas Kuhn, The STRUCTURE OF SCIENTIFIC REVOLUTIONS ( $3^{\text {rd }}$ ed., 1996).

10 See Brian R. ChefFins, The TRAJECTORY of (CORPORATE LAW) SCHOLARSHIP: AN INAUGURAL LECTURE GIVEN IN THE UNIVERSITY OF CAMBRIDGE, OCTOBER 2003 12-13 (2004). 
upon Kuhn to describe trends in corporate law theory. ${ }^{11}$ I argued when I discussed Kuhn in a 2004 publication that it was unclear whether his characterization of scientific endeavour could be used appropriately to analyze corporate law theory trends. ${ }^{12}$ I will make that point briefly again here. For present purposes, however, it will generally be assumed that Kuhn's work on scientific endeavour can be drawn upon to characterize the development of corporate law theory. From this departure point, this paper analyzes Blair and Stout's team production theory by reference to the Kuhnian framework they have invoked and in so doing argues that characterizing the team production model as part of a new corporate law paradigm is problematic in two basic respects.

First, it is open to question whether the team production model constitutes a sufficiently radical departure from other theories to qualify as a new paradigm. In Kuhnian terms a new paradigm emerges after an intellectual crisis sets the stage for a "paradigm shift". It follows that the team production model, as the core element of a new paradigm, should have constituted a fundamental departure from received wisdom. It is far from clear that their theory qualifies. The idea that boards of publicly traded companies constitute mediating hierarchs harkens back to a "managerialist" conception of the corporation that was during the mid- $20^{\text {th }}$ century associated with a highly influential separation of ownership and control theory of publicly traded companies. Moreover, Blair and Stout did not reject outright in their 1999 article what was at the time the dominant intellectual construct in corporate law, the nexus of contracts model of the corporation. Instead, Blair and Stout said their intention

11 Ibid., 51-53, 62-66; Alan J. Meese, The Team Production Theory of Corporate Law: A Critical Assessment, 43 WILLIAM \& MARY L. REV. 1629, 1633 (2002).

12 CHEFFINS, supra note 10, 65-66. 
was to use contractarian analysis as an intellectual departure point to develop a more fully rounded conception of corporate law. ${ }^{13}$

Second, even if the team production model can be distinguished sufficiently from prior corporate law theories to qualify as a new paradigm it is by no means assured that it will prevail in the battle of ideas in the manner required. Ronald Gilson and Reinier Kraakman made this point in a 2006 article that appeared in the same symposium issue as the article in which Blair and Stout invoked Kuhn to situate the team production model. ${ }^{14}$ Gilson and Kraakman, in addition to suggesting that it should fall to observers other than those who have developed a theoretical model to assess the model's significance, indicated that Blair and Stout's claim the team production model amounted to a new paradigm in corporate law scholarship was premature. ${ }^{15}$ This point is as salient as when Gilson and Kraakman made it, if not more so.

The most robust challenge Blair and Stout made to conventional wisdom in their 1999 article concerned shareholder primacy. According to team production theory directors should not privilege shareholders in the manner the shareholder primacy norm implies but instead should be disinterested trustees who faithfully represent the interests of all team members. ${ }^{16}$ Given that shareholder primacy is antithetical to the idea that boards of public companies should conduct themselves as mediating hierarchs balancing the interests of corporate constituencies, the team production model seemingly can only move to the forefront if shareholder primacy is being eclipsed. This does not appear to be happening. Instead, there

13 See infra notes 78, 81-82 and related discussion; CHEFFINS, supra note 10, 50-53.

14 Ronald J. Gilson and Reinier Kraakman, Clark's Treatise on Corporate Law: Filling Manning's Empty Towers, 31 J. CORP. L. 597 (2006).

$15 \quad$ Ibid., 603, n. 19.

16 Blair and Stout, supra note 1, 286. 
has been over the past few years a surge in shareholder influence in publicly traded corporations prompted primarily by activism campaigns hedge funds have launched.

The Financial Times suggested in 2013 that "Corporate America and activist investors have had a war; the activists have won."17 It logically follows, as a Wall Street Journal columnist observed in 2014, that activist investor priorities have "hardened into the default boardroom agenda."18 Directors thinking in this way are ill-suited to function as mediating hierarchs arbitrating in an unbiased way between key corporate constituencies. Correspondingly, the "inconvenient truth" of hedge fund activism refutes, at least for the time being, Blair and Stout's prediction of the team production model's emergence as a corporate law theory paradigm (or least sub-paradigm).

\section{IDENTIFYING CORPORATE LAW PARADIGMS}

Margaret Blair and Lynn Stout, citing the work of Thomas Kuhn, suggested in a 2006 Journal of Corporation Law article that their team production model was part of "a new paradigm appearing in corporate law scholarship."19 Stout, again citing Kuhn, made a similar claim in her 2012 book The Shareholder Value Myth. ${ }^{20}$ According to Stout, team production theory showed that businesses could not thrive if they were run according to shareholder primacy ideology, a "dominant paradigm of corporate purpose"” apt to be replaced by a new, alternative theory due to the prevalence of supposed anomalies inconsistent with shareholder primacy's essential precepts. ${ }^{21}$

17 Carl Icahn, Web Mogul, Fin. TIMES (London), Oct. 26, 2013, 24.

18 Denis K. Berman, For Activists There are No More Worlds to Conquer, WALL ST. J., April 23, 2014, B1.

19 Blair and Stout, supra note 5, 723, 733-37.

$20 \quad$ Stout, supra note 5.

$21 \quad$ Ibid., 58, 85. 
In order to assess whether team production theory is a candidate for paradigmatic status in the sense Kuhn intended the essential elements of the Kuhnian framework require explication and predecessor corporate law paradigms need to be identified. In an inaugural lecture published in the form of a 2004 monograph I analyzed various potential trajectories for the evolution of knowledge in intellectual disciplines and used corporate law scholarship as a case study. ${ }^{22}$ Kuhn's characterization of the development of scientific endeavour was one of the trajectories of which I took into account and, applying his intellectual framework to corporate law theory, identified potential corporate law paradigms. ${ }^{23}$ I draw liberally here on what I said then to summarize Kuhn's thinking and identify the corporate law theory paradigms relevant to team production theory.

According to Kuhn, once sufficiently convincing work is carried out in a given field to generate agreement concerning key theoretical precepts, research proceeds beyond an "immature" or "pre-paradigm" phase. ${ }^{24}$ With a tight research consensus in place, those working in the field are then spared the distracting re-examination of first principles and instead use the dominant "paradigm" as the departure point to solve "puzzles" posed yielding incremental improvements in analysis. Kuhn, focusing as he was on the development of scientific endeavour, referred to such research as "normal science", constituting "mop-up" work within a "mature" field.

Kuhn noted that those working in accordance within the precepts of "normal science" can encounter periodically inexplicable anomalies. The anomalies often prompt small adjustments within normal science as confirmation or disconfirmation of various theories

22 CHEFFINS, supra note 10. A slightly modified version was published in the Cambridge Law Journal: Brian R. Cheffins, The Trajectory of (Corporate Law) Scholarship, 63 CAMBRIDGE L.J. 456 (2004). A working paper version is available at http://ssrn.com/abstract $=429624$.

23 CHEFFINS, supra note 10, 13-14, 62-65.

24 Kuhn's seminal work on point is KUHN, supra note 9. 
falling with the governing paradigm proceeds. ${ }^{25}$ Another possibility, however, is that unexplained anomalies will accumulate sufficiently to destabilize the existing consensus. A "scientific revolution" will then occur that can then yield a new paradigm oriented around an entirely new theoretical framework. After this sort of "paradigm shift", normal science recommences and the stage is set for the cycle to repeat itself.

Assuming for the sake of argument that Kuhn's paradigm terminology can be applied to corporate law theory a separation of ownership and control thesis qualifies as the initial paradigm, at least with respect to U.S. public companies. ${ }^{26}$ An inconclusive debate during the opening decades of the $20^{\text {th }}$ century on the nature of corporate personality can be categorized as corporate law theory's "immature" phase. Matters changed with the 1932 publication of Adolf Berle and Gardiner Means' The Modern Corporation and Private Property ${ }^{27}$ which is widely credited with showing that a separation of ownership (shareholders) and control (top management) was prevalent in large public companies. ${ }^{28} \mathrm{~A}$ consensus subsequently emerged among corporate law academics - at least in the United States -- that for publicly traded companies Berle and Means' separation of ownership and control thesis was the appropriate intellectual departure point for analyzing corporate law.

\footnotetext{
25 Robert Cooter, Maturing into Normal Science: The Effect of Empirical Legal Studies on Law and Economics [2011] U. ILL. L. REV. 1475, 1476.

26 CHEFFINS, supra note 10, 38-40, 62-63.

27 Adolf Berle and Gardiner Means, The Modern Corporation And Private PROPERTY (1932).

28 Though Berle and Means were hailed for making the separation of ownership and control point empirically, the evidence they offered in fact was equivocal. See Brian Cheffins and Steven Bank, Is Berle and Means Really a Myth?, 83 Bus. HIST. REV. 443, 443, 453-54 (2009).
} 
In the classic "Berle-Means corporation"29 widely dispersed shareholders lacking sufficient financial incentives to intervene would remain passive as professionally trained executives managed the firm. A corporation of this sort could benefit from high-quality management because executives could be hired purely on the basis of their managerial capabilities. ${ }^{30}$ There was a danger, however, that due to insufficient accountability to shareholders or others those running large corporations would become "irresponsible oligarchs." ${ }^{31}$ For decades following the 1932 publication of The Modern Corporation and Private Property this possibility provided the departure point for the bulk of theoreticallyoriented corporate law scholarship in the United States. As Roberta Romano observed in a 1984 article on corporate law theory and law reform, Berle and Means' separation of ownership and control thesis became "the master problem for research." 32 To the extent that the thesis constituted the initial corporate law theory paradigm, the scholarship that addressed the legal and policy implications can be thought of as "normal science". 33

Berle and Means' separation of ownership and control thesis came to prominence in tandem with a philosophy of "managerialism" that was a core feature of an era of "managerial capitalism". ${ }^{34}$ During the late $19^{\text {th }}$ century and the opening decades of the $20^{\text {th }}$ century, the United States experienced what distinguished business historian Alfred Chandler would characterize as a "managerial revolution" where a growing division between

29 The term was coined by Mark Roe: Mark J. Roe, A Political Theory of American Corporate Finance, 91 CoLuM. L. REV. 10, 11 (1991).

30 Brian R. Cheffins, Introduction, THE History OF MODERN U.S. CORPORATE GOVERnANCE i, xi (Brian R. Cheffins, ed. 2011).

31 Carl Kaysen, The Social Significance of the Modern Corporation, 47 AMER. ECON. REV. 311, 316 (1957).

32 Roberta Romano, Metapolitics and Corporate Law Reform, 36 STAN. L. REV. 923, 923 (1984).

33 CHEFFINS, supra note 10, 63.

34 For a succinct overview of the chronology and terminology, see GERALD F. DAVIS, Managed by the Markets: How FinAnCE RE-Shaped AMERICA 32-33, 62-63 (2009). 
ownership and control was accompanied by increasingly sophisticated managerial hierarchies and the development of an increasingly professional ethos among corporate executives. ${ }^{35}$ According to Chandler, who identified Berle and Means as the first to point out the separation of ownership and control, ${ }^{36}$ by the 1950 s and 1960s "managerial capitalism had triumphed" with the managerial enterprise being dominant in pivotal sectors of the U.S. economy. ${ }^{37}$

While a separation of ownership and control creates risks of managerial abuse of power, in the decades immediately following World War II only rarely did executives fail to fulfil the responsibilities associated with the stewardship of corporate assets. ${ }^{38}$ This can plausibly be attributed - as indeed Lynn Stout has done - to the mind set of executives during the managerial capitalism era. She has suggested directors and executives of managerialist public companies were faithful corporate servants because they "viewed themselves as stewards or trustees charged with guiding a vital and economic and social institution." 39

According to Stout a beneficial by-product of post-World War II managerial attitudes was that "managerial capitalism worked surprisingly well for dispersed and powerless

35 Alfred D. Chandler, The Visible HAND: The MANAGERIAL REVOlution in AMERICAN BUSINESS 9, 484 (1977).

36 Alfred D. Chandler, The Competitive Performance of U.S. Industrial Enterprises since the Second World War, 68 Bus. HIST. REV. 1, 14 (1994). In fact, others had remarked upon the phenomenon previously but did not offer the extensive documentation Berle and Means provided: Cheffins and Bank, supra note 28, $452-53$.

37 Alfred D. Chandler, The United States: Seedbed of Managerial Capitalism in MANAGERIAL HIERARCHIES: COMPARATIVE PERSPECTIVES ON THE RISE OF THE MODERN INDUSTRIAL ENTERPRISE (Alfred D. Chandler and Herman Daems eds., 1980), 35.

38 Cheffins, supra note 30, xi-xii; Alfred F. Conard, Beyond Managerialism: Investor Capitalism?, 22 J.L. REF. 117, 123 (1988) ("During the first half of the twentieth century, the self-serving antics of managers seemed relatively innocuous"); DAVID SKEEL, ICARUS IN THE BOARDROOM 106 (2005) (saying that while US business culture is susceptible to counterproductively risky "Icaran" tendencies during the decades following the Depression "It became much harder for an Icaran entrepreneur to disguise what he was doing. For a time, at least, Icarus had been tamed.")

39 Stout, supra note 9, 1171. 
shareholders." ${ }^{40}$ Management, however, did not focus myopically on stockholders.

According to Stout, boards and executives who embraced the managerialist philosophy did not see themselves "as mere agents of shareholders." stewards running their companies "in the interests of a wide range of beneficiaries. Certainly they looked out for investors' interests, but they looked out for the interests of employees, customers, and the nation as well.",42

Stout, in offering her favorable verdict on managerial capitalism, concurred in large measure with Adolf Berle. While Berle and Means' separation of ownership and control thesis implied a potentially detrimental lack of managerial accountability, in the foreword to a 1959 book, The Corporation in Modern Society, Berle said "The principles and practice of big business in 1959 seem to be considerably more responsible, more perceptive and (in plain English) more honest than they were in 1929." "43 In a 1962 law review article he similarly noted that serious corporate scandals were "happily, rare" and acknowledged that conflicts of interest between managers and shareholders had not become more pronounced despite an acceleration of the separation of ownership and control in the three decades following the publication of The Modern Corporation and Private Property. ${ }^{44}$

There was in addition agreement between Berle and Stout on the goals and aspirations of executives during the era of managerial capitalism. Coincident with the publication of The
$40 \quad$ Ibid.
$41 \quad$ Ibid.
$42 \quad$ Ibid. (footnote omitted).
43 Adolf A. Berle, Foreword, The CORPORATION In MODERn SOCIETY ix, xiii (Edward S. Mason, ed., 1959).

44 Adolf A. Berle, Modern Functions of the Corporate System, 62 CoLuM. L. REV. 433, 437, 438, n. 9 (1962). One should not assume, however, that unsavory behavior was entirely absent in US public corporations in the mid- $20^{\text {th }}$ century. For examples, see Donald C. Hambrick, Just How Bad Are Our Theories? A Response to Ghoshal, 4 ACAD. MGMT. LEARNING \& EDUC. 104, 106 (2005). 
Modern Corporation and Private Property Berle engaged in a well-known debate with E.

Merrick Dodd with, in Berle's words, "the writer holding that corporate powers were held in trust for shareholders while Professor Dodd argued that these powers were held in trust for the entire community.",45 Berle conceded in 1954 that "(t)he argument ha(d) been settled (at least for the time being) squarely in favor of Professor Dodd's contention."46 Berle elaborated, saying that corporations, as "trustees for the community," must "provide a given set of goods and services for the community and in so doing so must provide employment for a great number of people" and should "assure the continued stability, health, and serviceability of their industries." ${ }^{47}$ He added in his foreword to The Corporation in Modern Society "modern directors are not limited to running business enterprise for maximum profit, but are in fact and recognized in law as administrators of a community system." shareholders fare under this system? Berle said, consistent with Stout's verdict on managerial capitalism, that shareholders usually did "well, even though stockholders do not hold the center of the corporate stage....,49

Berle's managerialist views were mainstream for the time. A 1961 Harvard Business Review survey of 1700 senior managers found $83 \%$ agreed it was unethical for "executives to act in the interests of shareholders alone, and not also in the interests of employees and

45 Adolf A. Berle, The $20^{\mathrm{TH}}$ Century Capitalist Revolution 169 (1954). On the 1930s debate between Berle and Dodd see C.A. Harwell Wells, The Cycles of Corporate Social Responsibility: An Historical Retrospective for the Twenty-first Century, 51 KANSAS L. REV. 77, 87-99, 101-4 (2002); Dalia Tsuk, From Pluralism to Individualism: Berle and Means and $20^{\text {th }}$-Century American Legal Thought, 30 LAW \& SoCIAL INQ. 179, 205-9 (2005); William W. Bratton and Michael L. Wachter, Shareholder Primacy's Corporatist Origins: Adolf Berle and The Modern Corporation, 34 J. CoRP. L. 99, 122-35 (2008).

$46 \quad$ BERLE, supra note 45, 169.

$47 \quad$ Ibid., 170.

48 Berle, supra note 43, xii.

49 BERLE, supra note 45, 170. 
consumers...."50 More generally, according to Harwell Wells, during the 1950s and 1960s the idea that executives "were responsible no longer for shareholders alone, but for other constituencies and, indeed, society at large..." was accepted by a "wide swathe of individuals, from leftist social critics, to moderate theorists of the corporation, to senior executives themselves...."51

Again, according to Kuhn's scientific methodology typology, "paradigm shifts" are preceded by the emergence of doubts concerning the existing paradigm followed by a "scientific revolution" yielding a new paradigm. ${ }^{52}$ With respect to corporate law theory, robust questioning of the separation of the ownership and control paradigm was evident by the early 1970s. As Henry Manne said in 1973:

"We have begun to note a whole series of questions related to the nature of the firm, particularly large, publicly-held corporations. Here the issue of discontinuities in the interests of shareholders and managers, popularly raised by Berle and Means in 1933, shows more vitality than seemed likely only a few years ago."

Continuing with the Kuhnian analogy, the accumulation of anomalies was followed during the late 1970s and the 1980s with a scientific revolution in the area of corporate law theory that culminated with a paradigm shift in favor of the nexus-of-contracts model of the

$50 \quad$ Raymond C. Baumhart, How Ethical are Businessmen?, HARV. Bus. REV., July-Aug. 1961, 6, 10, quoted in Jeffrey N. Gordon, The Rise of Independent Directors in the United States, 1950-2005: Of Shareholder Value and Stock Market Prices, 59 STAN. L. REV. 1465, 1512 (2007).

$51 \quad$ Harwell Wells, "Corporation Law is Dead": Heroic Managerialism, Legal Change, and the Puzzle of Corporation Law at the Height of the American Century, 15 U. PENN. J. BUS. L. 305 326, 331 (2013).

$52 \quad$ Supra note 24 and related discussion.

53 Henry G. Manne, The Limits and Rationale of Corporate Altruism: An Individualistic Model, 59 VA. L. REV. 708, 708-9 (1973). 
corporation. ${ }^{54}$ Strongly influenced by economists who departed from economic orthodoxy and treated the firm as a nexus of contracting relationships rather than a "black box", "contractarian" 55 corporate law academics prompted "a revolution in corporate law scholarship." ${ }^{56}$ The revolution, according to a 2013 book on corporate law theory by Marc Moore, resulted in an "objectively indisputable fact: that the contractarian paradigm is unquestionably the dominant ideological reference point with the field of Anglo-American corporate law and governance today.",

To the extent that the nexus of contracts model was a new paradigm, the paradigm shift was complete by the early 1990s. ${ }^{58}$ As William Bratton said in 1992 of contractarian scholars exemplified by Frank Easterbrook and Daniel Fischel, "the campaign has ended with victory achieved."59 Blair and Stout acknowledged the prevalence of contractarian thinking in their 1999 team production article, saying it had "become common for both economic and legal theorists to view a corporation as a 'nexus of contracts'...."60 They observed similarly

\footnotetext{
54 Marc T. Moore, Corporate Governance in the Shadow of the StATE 62, 67 (2013).
}

55 Jack Coffee has been credited for first using the term "contractarian" to describe those engaging in nexus of contracts analysis: Brian Dean Abramson, Why the Limited Liability Company Should Sound the Death Knell of the Application of the Application of the "Nexus of Contracts" Theory of the Corporation, 1 FLA. INT. UNIV. L. REV. 185, 187, n. 8 (2006), citing John C. Coffee, The Mandatory/Enabling Balance in Corporate Law: An Essay on the Judicial Role, 89 COLUM. L. REV. 1618 (1989).

56 Jason Scott Johnson, The Influence of "The Nature of the Firm" on the Theory of Corporate Law, 18 J. CORP. L. 213, 231 (1993); see also Lewis A. Kornhauser, The Nexus of Contracts Approach to Corporations: A Comment on Easterbrook and Fischel, 89 CoLUM. L. REV. 1449, 1449 (1989) ("Critics and advocates agree that a revolution, under the banner 'nexus of contracts' has in the last decade swept through the legal theory of the corporation.") For additional background see CHEFFINS, supra note 10, 44-47.

57 MOORE, supra note 54, 71-72.

58 CHEFFINS, supra note $10,49$.

59 William W. Bratton, The Economic Structure of the Post-Contractual Corporation, 87 Nw. UNIV. L. REV. 180, 190 (1992). 
in a 2001 article that "Contractarian thinking...preoccupies modern corporate law scholarship.",61

Agency cost or principal/agent theory, which presupposes that in economic terms an agency relationship arises when one person ("the agent") has been engaged by another ("the principal") to perform a service with some decision-making authority being delegated to the agent, ${ }^{62}$ was a pivotal feature of the newly dominant contractarian analysis. ${ }^{63}$ Blair and Stout argued in their 1999 article that the growing prominence of agency cost theory had a significant knock-on effect, namely helping to foster the dominance of a "shareholder primacy norm." ${ }^{, 64}$ They said the principal/agent model

"has given rise to two recurring themes in the literature: First, the central economic problem addressed by corporation law is reducing 'agency costs' by keeping directors and managers faithful to shareholders' interests; and second, that the primary goal of the public corporation is - or ought to be - maximizing shareholders' wealth."

In the corporate law realm academics did deploy agency theory primarily to examine the relationship between shareholders of publicly traded corporations on one hand and senior

$61 \quad$ Margaret M. Blair and Lynn A. Stout, Trust, Trustworthiness, and the Behavioral Foundations of Corporate Law, 149 U. PA. L. REV. 1735, 1737, n. 2 (2001). David Millon, in an article critiquing team production theory, offered a similar verdict on this point, noting that with respect to corporate law scholarship "a law-and-economics approach predominates": New Game Plan or Business as Usual? A Critique of the Team Production Model of Corporate Law, 86 VA. L. REV. 1001, 1009 (2000).

62 Michael C. Jensen and William H. Meckling, Theory of the Firm: Managerial Behavior, Agency Costs and Ownership Structure, 3 J. FIN. ECON. 305, 308 (1976).

63 CHEFFINS, supra note 10, 45.

64 Blair and Stout, supra note 1, 253. They were not the first academics to use this term. On various predecessors, see D. Gordon Smith, The Shareholder Primacy Norm, 23 J. CORP. L. 277, 278, n. 1 (1998).

$65 \quad$ Blair and Stout, supra note 1, 248-49. Other academics have similarly suggested the principal/agent model implies shareholder primacy. See, for example, Meese, supra note 11, $1631,1639$. 
management on the other. ${ }^{66}$ Nevertheless, neither principal/agent theory nor contractarian analysis was inextricably linked to shareholder primacy. For instance, agency cost theory is potentially applicable to a wide range of economic contexts, not just manager/shareholder interaction in public companies. ${ }^{67}$ As Blair and Stout pointed out themselves in their 1999 article, "the public corporation is hardly unique in its use of agents." 68

With respect to contractarian analysis and the shareholder primacy norm, as noted corporate law academic Melvin Eisenberg has said, "It is commonly thought that the nexusof-contracts conception is connected in some fundamental way to the concept of shareholder primacy. It isn't." ${ }^{39}$ Instead, with shareholders being merely one constituency that is part of the nexus of contracts it is not obvious a priori why managers should assign shareholders special priority. ${ }^{70}$ Indeed, Jonathan Macey, another distinguished corporate law academic, has said "(t)he nexus-of-contracts approach to the corporation appears to be strongly at odds" with the proposition that corporations and directors should maximize value for shareholders, and shareholders alone. ${ }^{71}$

66 See, for example, Millon, supra note 61, 1001 (“...the currently dominant analytical approach to corporate law...is the principal-agent model of the relationship between the corporation's shareholders and its management.")

$67 \quad$ For instance, Easterbrook and Fischel, the prominent contractarian corporate law scholars, used the example of employees generally rather than corporate executives specifically to introduce the concept of agency costs in their widely cited 1991 book: FRANK H. EASTERBROOK AND DANIEL R. FisCHEL, THE ECONOMIC STRUCTURE OF CORPORATE LAW 10 (1991).

$68 \quad$ Blair and Stout, supra note 1, 249.

69 Melvin A. Eisenberg, The Conception That the Corporation is a Nexus of Contracts, and the Dual Nature of the Firm, 24 J. CORP. L. 819, 833 (1999).

70 CHEFFINS, supra note 10, 47-48.

71 Jonathan R. Macey, Fiduciary Duties as Residual Claims: Obligations to Nonshareholder Constituencies From a Theory of the Firm Perspective, 84 CORNELL L. REV. 1266, 1267 (1999). See also Julian Velasco, The Fundamental Rights of the Shareholder, 40 U.C. DAVIS L. REV. 407, 445 (2006) (contractarian theory "would seem to open the door quite widely to the consideration of the interests of other constituencies"). 
While neither agency theory nor the nexus of contracts model necessarily compel the invocation of shareholder primacy, contractarian scholars did as a practical matter tend to ascribe pre-eminence to shareholders in the manner shareholder primacy implies. Advocates of the nexus of contracts model would, for instance, draw attention to shareholders' status as "residual claimants," 72 in the sense that the return shares deliver is based on what is left over after satisfaction of claims by employees, creditors and others entitled to "fixed" returns. ${ }^{73}$ Under such circumstances, the argument went, shareholder value will tend to coincide with corporate success because every step a corporation takes can affect shareholder wealth whereas fixed claimants will be indifferent to corporate policymaking unless the likelihood of default or termination of contractual relations increases materially. ${ }^{74}$ Contractarians also cited contracting costs to justify shareholder primacy. ${ }^{75}$ They suggested the pre-eminent position of shareholders in the corporate nexus of contracts reflected the fact that creditors, employees and customers, due to the fixed nature of their claims, could bargain more readily for suitable protection than shareholders making the open-ended investment associated with corporate equity. $^{76}$

\section{Situding The TeAm PROdUction Model}

72 On contractarians making this move, see CHEFFINS, supra note 10, 47-48; Macey, supra note 71, 1273.

73 On why shareholders can be thought to constitute residual claimants and other corporate constituencies constitute fixed claimants, see BRIAN R. CHEFFINS, COMPANY LAW: THEORY, STRUCTURE AND OPERATION 42, 54, 71, 87 (1997).

74 See, for example, EASTERBROOK AND FISCHEL, supra note 67, 38, 68. For an overview of the logic involved, see Ronald Chen and Jon Hanson, The Illusion of Law: The Legitimating Schemas of Modern Policy and Corporate Law, 103 MicH. L. REV. 1, 46-48 (2004).

75 CHEFFINS, supra note 10, 48; MoORE, supra note 54, 76-77.

76 See, for example, Jonathan R. Macey and Geoffrey P. Miller, Corporate

Stakeholders: A Contractual Perspective, 43 U. TORONTO L.J. 401, 416-19 (1993). For additional background on this line of reasoning see Chen and Hanson, supra note 74, 52-57. 
Assuming that developments in corporate law theory can be described by reference to Kuhn's typology of scientific endeavour, in order for the team production model to constitute the core element of a new corporate law paradigm the theory should constitute a marked intellectual departure from the past. Otherwise, the model would likely amount merely to "mop up" work or "normal science" within the confines of the existing paradigm. Moreover, it will be problematic if team production theory harkens back to a dominant mode of analysis preceding the paradigm it ostensibly is replacing because this will imply that the trajectory of corporate law scholarship is not a Kuhnian journey but instead is primarily cyclical.

On both counts, the team production model's status as a new corporate law paradigm is problematic. When one refers back to Blair and Stout's 1999 article, their characterization of team production theory is more closely akin to contractarian "normal science" than it is to a new paradigm. Moreover, to the extent that the team production model can be distinguished from the nexus of contracts "paradigm" or its principal/agent and shareholder primacy "sub-paradigms", ${ }^{77}$ the theory arguably harkens back to what can be thought of as an earlier (sub-)paradigm - managerialism - as much as it provides the platform for fresh thinking.

\section{A. "Normal Science"}

In Kuhnian terms academic endeavour that constitutes "mop-up" work within a "mature" field will not constitute a new paradigm because this sort of "normal science" occurs within the intellectual confines of the existing paradigm. Only when the prevailing consensus has been disrupted by an accumulation of anomalies can a "paradigm shift" occur.

77 Kuhn never referred to a "sub-paradigm" but others relying on Kuhn's analytical framework have done so. See, for example, Neil Warren, Is a Scientific Revolution Taking Place in Psychology: Doubts and Reservations, 1 SCIENCE STUD. 407, 409 (1971); Tom Mouck, The "Revolution" in Financial Reporting Theory: A Kuhnian Interpretation, 20 ACCTING. HisT. J. 33, 38, 41 (1993). 
Hence, the emergence of team production theory as a new paradigm presupposes the discrediting of prior dominant models. Blair and Stout, in their 1999 article on the team production model, did not characterize the relevant literature in this way. Instead, they emphasized continuity with contractarian analysis and treated the nexus of contracts model as a key departure point rather than as an outdated and discredited intellectual construct. ${ }^{78}$ In Kuhnian terms, it seems Blair and Stout were engaging in normal science with the nexus of contracts approach as the dominant paradigm.

Blair and Stout did not adopt the nexus of contracts model wholesale in their 1999 article. They argued that the public corporation was "not so much a 'nexus of contracts' (explicit or implicit) as a 'nexus of firm-specific investments' in which several different groups...find it difficult to protect their contribution through explicit contracts."79 Moreover, in a 1999 response to an article commenting on team production theory Blair and Stout pointed out that "the team production approach highlights the necessity of finding noncontractual means of inducing corporate stakeholders, including shareholders, to trust each other enough to invest in team production." ${ }^{80}$ Nevertheless they said in their original 1999 article that their approach to public corporations "does not reject...contractarian thinking, but builds upon it by acknowledging the limits of what can be achieved by explicit contracting." $" 81$ Moreover, they indicated team production theory was "consistent with the 'nexus of contracts' approach to understanding corporate law" and explicitly "locate(d) the

\footnotetext{
78 Others have noted previously the continuity between the nexus of contracts model and team production theory: Meese, supra note 11, 1644-45; René Reich-Graefe, Deconstructing Corporate Governance: Absolute Director Primacy, 5 BROOK. J. CORP. FIN. \& COM. L. 38788 (2011).

$79 \quad$ Blair and Stout, supra note 1, 275.

80 Margaret M. Blair and Lynn A. Stout, Response to Peter C. Kostant's “Exit, Voice and Loyalty in the Course of Corporate Governance and Counsel's Changing Role, $28 \mathrm{~J}$. SOCIO-ECONOMICS 251, 252 (1999) (emphasis added).

$81 \quad$ Blair and Stout, supra note 1, 320.
} 
mediating hierarchy model of the public corporation within the nexus of contracts tradition" 82 In Kuhnian terms, then, Blair and Stout were seeking primarily to execute an adjustment in relation to the dominant contractarian paradigm rather than identify anomalies calling the paradigm into question.

While Blair and Stout emphasized in their 1999 article continuity between team production theory and nexus of contracts thinking the situation was different with the principal-agent model and shareholder value norm often associated with contractarian analysis. As they said, "we take issue with both". ${ }^{83}$ With agency theory, however, Blair and Stout did not seek to turn the received wisdom entirely on its head. Instead, they acknowledged "principal-agent analysis has been very useful in analysing certain kinds of contractual relationships." ${ }^{\prime 84}$ What they sought to question was what they referred to as the "grand-design principal-agent model", which assumed that there was in every firm a principal - the shareholders in the case of a corporation - who was understood to be the owner as well as the residual claimant. ${ }^{85}$ Blair and Stout said that because "a public corporation is a team of people who enter into a complex agreement to work together for their mutual gain" what they referred to as "the peak of the pyramid" should be "occupied not by some owner/principal, but (the) board of directors." ${ }^{, 86}$ Hence, Blair and Stout did not reject principal-agent analysis outright in the manner one would expect with a paradigm shift but rather sought to recast it in the context of the public corporation. Arguably this was more "normal science."

$82 \quad$ Ibid., 254, n. 17.

83 Ibid., 249. See also Margaret M. Blair, Corporate Law and the Team Production Problem in RESEARCH HANDBOOK ON THE ECONOMICS OF CORPORATE LAW 33, 34 (Claire A. Hill and Brett H. McDonnell eds., 2012) ("The team production framework challenged the 'principal-agent' framework....").

$84 \quad$ Blair and Stout, supra note 1, 259.

85 Ibid., 262-63.

86 Ibid., 278-79. Blair and Stout explicitly conceded that their "model applie(d) to primarily to public - not private - corporations." See ibid. at 281. 
Shareholder primacy was a different story. There would be no mop up work in relation to this (sub-)paradigm. Having identified the board of the public corporation as the "peak of the pyramid", Blair and Stout said

"the primary job of the board of directors is not to act as agents who ruthlessly pursue shareholders' interests at the expense of employees, creditors, or other team members. Rather, the directors are trustees for the corporation itself-mediating hierarchs whose job is to balance members' competing interests in a fashion that keeps everyone happy enough that the productive coalition stays together." ${ }^{87}$

Unlike with the nexus of contracts model and principal-agent theory, Blair and Stout made no effort in their 1999 article to reconcile the team production model with shareholder primacy. Instead, their "claim (was) that directors should be viewed as disinterested trustees charged with faithfully representing the interests not just of shareholders, but of all team members." $" 88$ Hence, as they said, their "view challenge(d) the shareholder primacy norm that has come to dominate the theoretical literature." $" 89$

Even if Blair and Stout's 1999 article challenged the shareholder primacy norm directly in a way that did not occur with the nexus of contracts model or principal-agent theory, applying the Kuhnian analogy again, Blair and Stout's initial presentation of the team production model could not at that point in time constitute a new paradigm. Kuhn's scientific revolutions pre-suppose the identification of anomalies and intellectual ferment as a precursor to a paradigm shift. ${ }^{90}$ With respect to corporate law theory, shareholder primacy was not facing that sort of challenge at the time Blair and Stout presented their team production

\footnotetext{
87 Ibid., 280-81 (emphasis in the original).

$88 \quad$ Ibid., 286.

$89 \quad$ Ibid., 253.

$90 \quad$ Supra note 24 and related discussion.
} 
model. They acknowledged in their 1999 article that "most contemporary corporate scholars tend to assume that directors' proper role is to maximize the economic interests of the corporation's shareholders." ${ }^{91}$ Or as Henry Hansmann and Reinier Kraakman said in their 2001 article The End of History of Corporate Law, "there is today a broad normative consensus that shareholders alone are the parties to whom corporate managers should be accountable...."92

In the intellectual milieu prevailing at the time Blair and Stout published their 1999 article, in Kuhnian terms the most the article could realistically achieve was to draw attention to anomalies that would help to foster the debate that could ultimately result in a consensus around a new paradigm. The manner in which they concluded the article illustrates the point. Having said "excessive and misleading" emphasis had been "placed on principal-agent problems in the corporate literature" they indicated "future debates about corporate governance will be more fruitful if they start from a better model" and they characterized the mediating hierarchy model as "a first step toward that better view."93 Hence, in Kuhnian terms Blair and Stout were implicitly conceding that while presentation of the team production model might help to launch the intellectual journey that would yield a new paradigm it was not as such the new paradigm.

91 Blair and Stout, supra note 1, 287. Other commentators concurred. See, for example, Eisenberg, supra note 69, 832 ("Most (although by no means all) corporate scholars subscribe to the norm of shareholder primacy...."); Millon, supra note 61,1010 ("It is common coin among commentators to speak of corporate law and fiduciary doctrines as mandating management regard for shareholder interests over those of other corporate constituencies"); Gerald F. Davis, The Twilight of the Berle-Means Corporation, 34 SEATTLE UNIV. L. REV. 1121, 1129 (2011) ("By the late 1990s, there was wide agreement among corporate managers, directors, shareholders, and many scholars that the corporation existed to create shareholder value").

92 Henry Hansmann and Reinier Kraakman, The End of History of Corporate Law, 89 GEO. L.J. 439, 441 (2001).

$93 \quad$ Blair and Stout, supra note 1, 328. 
The fact that in chronological terms Blair and Stout's 1999 article would not have itself heralded the launch of a new corporate law paradigm does not preclude team production theory from subsequently being a foundational element of such a (sub-)paradigm. As we will see in Part IV.A of the paper, shareholder primacy has faced a strong intellectual challenge since Hansmann and Kraakman proclaimed in 2001 " $(\mathrm{t})$ he triumph of the shareholderoriented model of the corporation."94 This intellectual ferment theoretically could have opened the way for a new paradigm oriented around the team production model. Before we canvass that possibility we will consider whether, whatever the current status of shareholder primacy, the team production model is more of an intellectual throwback rather than a forerunner.

\section{B. Managerialism Redux?}

It has been assumed to this point, consistent with Margaret Blair and Lynn Stout's invocation of Thomas Kuhn and his paradigm terminology, that Kuhn's work is relevant to corporate law scholarship. The appropriateness of this move cannot be taken for granted even though legal scholars have frequently borrowed from Kuhn to describe trends in the academic literature. ${ }^{95}$. The fact Kuhn was focusing on the development of scientific thought rather than intellectual endeavour generally is an obvious source of concern on this front.

Scientific inquiry involves explicit theory-building, data collection, hypothesis testing, replication and corroboration. ${ }^{96}$ Robert Cooter has argued that the recent flourishing of empirical legal scholarship has meant that the law and economics movement that began to transform academic writing about law in the 1970s and 1980s has matured into Kuhn's

\footnotetext{
$94 \quad$ Hansmann and Kraakman, supra note 92, 468.

95 CHEFFINS, supra note 10, 13.

96 Ibid., 6; Nancy Cook, Law as Science: Revisiting Langdell's Paradigm in the $21^{\text {st }}$ Century, 88 N.D. L. REV. 21, 28 (2012).
} 
"normal science". ${ }^{97}$ Empirical research and economic analysis more generally may have added a fresh "scientific" dimension to corporate law research. ${ }^{98}$ Still, explicit deployment of scientific methodology remains the exception to the rule in corporate law scholarship, which continues to be primarily oriented around doctrinal and policy-related research. ${ }^{99}$ Many legal academics even doubt whether deployment of scientific method is appropriate for the study of law. ${ }^{100}$ Correspondingly, drawing upon an analytical framework designed to account for the development of science to characterize corporate law scholarship trends is a problematic move. $^{101}$

Even if parallels between scientific endeavour and corporate law scholarship are sufficient to mean that Kuhn's work on scientific revolutions is potentially salient, it remains open to question whether changing trends in corporate law theory can be characterized as paradigm shifts. Kuhn's paradigm shifts cannot occur without paradigms and according to Kuhn a paradigm presupposes a tight research consensus which provides the platform for the "mop up" work associated with normal science. ${ }^{102}$ It is open to question, however, whether this has ever been achieved with corporate law theory. For instance, Berle and Means' separation of ownership and control analysis and the nexus of contracts model were much more influential and widely accepted in the United States than they ever were elsewhere. ${ }^{103}$

97 Cooter, supra note 25, 1479. See also Thomas Ulen, The Unexpected Guest: Law and Economics, Law and Other Cognate Disciplines, and the Future of Legal Scholarship, 79 CHI.-KENT L.REV. 403, 414-18, 426-27 (2004) (indicating that law and economics had made legal scholarship more scientific but bemoaning the paucity of empirical research); Jeffrey J. Rachlinski, Evidence-Based Law, 96 CORNELL L. REV. 901, 904 (2011) (referring to the "exponential growth" in empirical legal scholarship "in the past few years.")

98 CHEFFINS, supra note 10, 60-61.

$99 \quad$ Ibid., 61-62.

$100 \quad$ Ulen, supra note 97, 413.

101 CHEFFINS, supra note 10, 65.

102 Supra note 24 and related discussion.

103 CHEFFINS, supra note 10, 66. 
Hence, with corporate law scholarship it is only possible to speak of paradigms if the United States can be treated in isolation as the appropriate reference point.

Even setting the foreign angle to one side, it is unclear whether the research consensus required for there to be a paradigm in the Kuhnian sense has ever been present in the corporate law area. For instance, despite Moore's 2013 declaration of a corporate law "contractarian paradigm" and a 2001 acknowledgment by Blair and Stout that the nexus of contacts model "preoccupie(d) modern corporate law scholarship" 104 a substantial number of American corporate law academics were never converted. ${ }^{105}$ The situation has been similar with the shareholder primacy (sub-)paradigm. While Hansmann and Kraakman indicated that there was a "broad normative consensus" concerning the pre-eminence of shareholders, even when they made this claim adherence to shareholder primacy was not uniform among corporate law scholars. Robert Clark observed, for instance, in a response to papers published in a symposium marking the $20^{\text {th }}$ anniversary of his 1986 treatise on corporate law, "a major trend in legal scholarship since the publication of my treatise has been the elaboration and defense of differing viewpoints about the purposes of corporations and the proper allocation of powers and duties among their constituents." 106

If with respect to corporate law there have not been Kuhnian paradigms - thus precluding possible paradigm shifts to the team production theory - how might the model's intellectual contribution be characterized? Paradigm shifts constitute only one of a series of potential trajectories for corporate law scholarship. One possibility which is salient in this

\footnotetext{
$104 \quad$ Supra notes 54, 61 and related discussion.

105 CHEFFINS, supra note 10, 49, 66.

106 Robert C. Clark, Corporate Law (1986); Robert C. Clark, Major Changes Lead Us Back to Basics (A Response to the Symposium on My Treatise), 31 J. CORP. L. 591, 595 (2006).
} 
particular context is a cyclical dimension, in the sense that academic endeavour constitutes at least to some degree a continuing conversation about core questions. ${ }^{107}$

To the extent corporate law theory addresses a series of key recurring questions, one which qualifies is "On whose behalf are companies run?"108 The answer the team production model provides harkens back to managerialist thinking associated with Berle and Means' separation of ownership and control thesis. As mentioned, Blair and Stout saw the team production model as a challenger to shareholder primacy, with boards acting as trustees working to promote the interests of all team members rather than ultimately looking out only for shareholders. ${ }^{109}$ This echoes the managerialist thinking of Adolf Berle, who again characterized large corporations as "trustees for the community" with directors not being under an onus to run their companies "for maximum profit.".110

Identifying parallels between team production theory and the managerialist conception of the corporation is by no means novel. Harwell Wells, in a 2013 article on the historical relationship between managerialism and corporate law, flagged up the possibility that Blair and Stout, with their team production theory, "repackage managerialism."111 George Dent has likewise referred to the team production model as "(a) modern variation on managerialism." $" 112$

107 CHEFFINS, supra note 10, 23, 70-76. Other possibilities include market-driven improvement via competition in the marketplace for ideas and "fads and fashions":

CHEFFINS, op.cit., 67-70, 76-82

$108 \quad$ Ibid., 72.

109 Supra notes 88-89 and related discussion.

110 Supra notes 47-48 and accompanying text.

111 Wells, supra note 51, 352, n. 225.

112 George W. Dent, Corporate Governance: Still Broke, No Fix in Sight, 31 J. CoRP. L. 39, 51 (2005). 
Stout has, writing independently from Blair, recently evinced considerable enthusiasm for managerialism. Indeed, consistent with the proposition that influential schools of thought can have a cyclical dimension, she has suggested a managerialist comeback could be on the cards. She has conceded managerial capitalism was "hardly perfect" but nevertheless maintains it generated "good results". ${ }^{113}$ Shareholder primacy, she says, has been a different story. In a 2013 article published as part of the proceedings of the fourth Berle symposium Stout argued that because empirical evidence showed shareholder primacy had failed to deliver superior returns for the supposed beneficiaries - stockholders - "it (was) time to move on to another theory." "114 What will it be? Stout predicted -"albeit with caution" - that "American corporations are likely to respond to the disappointments of shareholder primacy by returning to what worked for more than half a century: some form of managerial capitalism." 115 Stout acknowledged that the new corporate philosophy was "unlikely to be called managerial capitalism. But it will bear the hallmarks of managerialism."

\footnotetext{
113 Stout, supra note $9,1171$.

$114 \quad$ Ibid., 1181.
}

$115 \quad$ Ibid. See also Chris Gay, Are Shareholders Their Own Worst Enemies?, U.S. News \& WORLD REPORT, Sept. 5, 2012 (interview with Stout in which she was asked whether some form of managerialism would replace shareholder value and she replied that "The lovely thing about the business world is that, given a little breathing room, it's highly adaptable.") 116 Stout, supra note 9, 1182. Stout elaborates in this article by saying that, consistent with what would be expected if the managerialism she had in mind would be akin to that which was influential in the 1950s and 1960s, the companies in question would "be owned by dispersed passive investors with little or no influence over the firms' affairs" - ibid. The two examples of "neo-managerialist firms" to which she draws attention, however, do not fit the traditional managerialist pattern. One is firms going public "with multiple share classes that allow the firms' founders and executives to retain voting control" (ibid.). In firms of this sort there will be dominant shareholders whose influence over senior executives will mean that management will be unable to exercise the sort of autonomy typically associated with managerialism. The other example Stout provides is private equity firms which have gone public, such as Blackstone, Carlyle Group, KKR and Apollo (ibid., 1183). The founders of these firms own dominant stakes, reinforced by the issuance of shares to the public with reduced voting rights attached. Yet again in firms of this sort executives will necessarily lack the freedom of action typically associated with managerialism. 
This means we have from Lynn Stout a prediction for the trajectory of corporate law scholarship in addition to the claim that team production theory will become be a key element of a new corporate law theory paradigm. Can Stout's 2013 prediction of "managerialism redux" be reconciled with her assertions concerning the team production model? Since parallels can readily be drawn between team production theory and the managerialist conception of the corporation, it might seem so. In fact, since managerialism appears to leave boards little room to perform the mediating function that is integral to team production theory any such reconciliation can be at best partial. $^{117}$

Under team production theory the board is an independent body at the peak of the corporate hierarchy that serves as the final arbiter when executives, shareholders, employees and other corporate constituencies cannot resolve disputes at lower levels. ${ }^{118}$ This type of board is a far more important governance mechanism than the type of board associated with managerial capitalism. As the term "managerialism" implies, with this intellectual model senior executives, not directors, occupy centre-stage. According to Stephen Bainbridge, under managerialism "Directors are figureheads, while shareholders are nonentities. Managers are thus autonomous actors free to pursue whatever interests they choose." 119 With "figurehead" directors, managerialist boards are unlikely candidates to function as the

117 Another disconnect between team production theory and managerialism is that the latter was informed by concerns about corporate power and a social ethos predicated upon managers having a public role to play whereas Blair and Stout structured the team production model with an explicitly economic foundation oriented around the protection of firm-specific investments put at risk in collaborative ventures. See Wells, supra note 51, 352, n. 225; Dent, supra note 112,51 . It has indeed been said that describing team production theory as a reformulation of the managerialism of the 1960s is a mischaracterization: Peter C. Kostant, Team Production Theory and the Progressive Corporate Law Agenda, 35 U.C. DAVIS L. REV. 667, 690 (2002).

118 Blair and Stout, note 1, 279, 282.

119 StePhen M. BAInbridge, The NEW CORPORATE GovernANCE IN THEORY AND PRACTICE 9 (2008); see also Stephen M. Bainbridge, Director Primacy: The Means and Ends of Corporate Governance, 97 Nw. UNIV. L. REV. 547, 561 (2003) (quoting Adolf Berle and E. Merrick Dodd to illustrate the point). 
neutral mediating hierarchs the team production model contemplates. Indeed Dent claims that "When managers dominate boards, the team production theory is unworkable." 120

There can be little doubt that boards of the managerialist corporations of the 1950s and 1960s were fundamentally ill-suited to operate in accordance with team production theory. During these decades, nearly half of the individuals serving as directors of public companies worked for the same firm in an executive capacity, less than one-quarter were genuinely independent and boards were expected to operate as little more than a sounding board for the chief executive officer. ${ }^{121}$ Under such circumstances, boards were "largely passive instruments of the CEO" and "an extension of management." 122 Hence, during the "heyday of...corporate managerialism" $" 123$ boards could not realistically perform the role assigned to them by team production theory.

Stout's recent scholarship does not provide an obvious path for reconciling her support for managerialism with her board-centric team production theory. Stout, in the 2013 article where she offered conjectures concerning the return of managerialist corporations, did not discuss team production theory and cited the 1999 team production article she co-wrote with Blair only once so as to make a point concerning corporate law doctrine. ${ }^{124}$ Likewise, in The Shareholder Value Myth she offered little explicit guidance on the interrelationship between team production theory and a potential re-emergence of managerialism. ${ }^{125}$

\footnotetext{
120 Dent, supra note 112, 56.

121 Gordon, supra note 50, 1473-75, 1513-14.

$122 \quad$ Ibid., 1511, 1514.

123 Ibid., 1511.

124 Stout, supra note 9, 1171, n. 15.

125 On analysis of team production theory in this monograph, see STOUT, supra note 5, 80-85.
} 
Jonathan Macey is in no doubt where Stout stands. He maintained in a review of The Shareholder Value Myth that the key words in the book were "managerial choice" and suggested that her "message, slightly obscured, but discernible nevertheless, is that managers should run the corporation with plenary authority and with no reference to the shareholders' interests." 126 Whether Stout in fact is, as Macey asserts, a believer in "managerial primacy", ${ }^{127}$ is open to question given the board-centric nature of team production theory. Nevertheless, when Stout discussed directors in conjunction with executives in The Shareholder Value Myth, her standard formulation was "directors and executives (or managers)", ${ }^{128}$ implying in a managerialist fashion that boards and management are on the same team.

If directors and executives are equated in the manner Stout has done in her 2012 book, it becomes doubtful whether directors will be able to exercise the independent judgment required for them to be the mediating hierarchs team production theory contemplates. Perhaps she is simply being realistic. Various observers have suggested present day boards are too much under the sway of senior executives for boards to function in the manner team production theory presupposes. ${ }^{129}$ For present purposes, however, the key point is that

126 Jonathan Macey, Sublime Myths: An Essay in Honor of the Shareholder Value Myth and the Tooth Fairy, 91 TEX. L. REV. 911, 914 (2013).

$127 \quad$ Ibid., 917.

128 See, for example, STOUT, supra note 5, 3 ("This sort of thinking drives directors and executives to run public firms like BP with a relentless focus on raising stock price....many individual directors and executives feel uneasy about such strategies"), 35, 36 (characterizing the managerial agents in principal/agent theory as "directors and executives"), 47 (describing strategies that could be adopted to encourage "directors and executives" to embrace shareholder value), 59 (discussing academics who believe "directors and executives" should have objectives other promoting shareholder value), 108 (saying that theories such as team production do not always provide clear guidance on what "directors and managers" should adopt as a corporation's goal).

129 Meese, supra note 11, 1699-1700; John C. Coates, Measuring the Domain of Mediating Hierarchy: How Contestable Are U.S. Public Corporations?, 24 J. CoRP. L. 837, 
Stout's predictions that there will be a (sub-)paradigm shift to team production theory and a return to managerial capitalism conflict and cannot be readily reconciled.

\section{The InCONVENIENT TRUTH OF Hedge Fund ACTIVISM}

Assume, despite the doubts expressed in Part III.B, that with respect to corporate law theory one can plausibly characterize the development of corporate law theory in Kuhnian terms. Team production theory's position nevertheless remains somewhat unclear. While Blair and Stout have suggested it may be part of a new corporate law paradigm, the model also can plausibly be characterized as an example of contractarian "normal science" (Part III.A). The team production model also harkens back to the separation of ownership and control paradigm in the sense that it might be managerialism revisited (Part III.B).

While the interrelationship between team production theory and prior corporate law theory paradigms is not straightforward, Blair and Stout did unambiguously identify the team production model in their 1999 article as a challenger to the notion of shareholder wealth maximization. ${ }^{130}$ Could the team production model emerge as a (sub-)paradigm to replace shareholder primacy? In Kuhnian terms this could only occur if inexplicable anomalies afflicted the shareholder primacy norm so as to set the stage for a paradigm shift. ${ }^{131}$ As we will see now, intellectual challenges to the shareholder value norm accelerated in pace after Blair and Stout introduced the team production model. Conceivably, then, sufficiently serious anomalies have emerged for a paradigm shift to occur that would be oriented around

845-46 (1999); George W. Dent, Academics in Wonderland: The Team Production and Director Primacy Models of Corporate Governance, 44 HoU. L. REV. 1213, 1230-31 (2008). $130 \quad$ Supra notes 88-89 and related discussion.

131 Supra notes 25, 78 and accompanying text. 
team production theory. A narrative of this sort must confront, however, an "inconvenient truth" 132 in the form of hedge fund activism.

Interventions by hedge funds are currently compelling executives in U.S. public corporations to treat shareholder value as a higher priority than was the case when Blair and Stout unveiled team production theory. Directors otherwise inclined to act as mediating hierarchs in the balanced fashion team production theory contemplates correspondingly might well feel compelled to continue to treat shareholders as their top priority. To the extent this is true, hedge fund activism will postpone, perhaps indefinitely, the displacement of shareholder primacy required for the ascension of team production theory as a corporate law (sub)paradigm.

\section{A. Shareholder Primacy Anomalies}

In their 1999 article Blair and Stout acknowledged that "shareholder primacy ha(d) become increasingly popular" as the $20^{\text {th }}$ century drew to a close. ${ }^{133}$ Moreover, they said that law and economics scholars who were advocates of shareholder wealth maximization and "progressive" academics who opposed this normative objective still agreed "that, as a descriptive matter, American corporate law follows the shareholder primacy model."134 A core element of Blair and Stout's critique of shareholder primacy was that this diagnosis of corporate law was erroneous. They argued that corporate law doctrines instead "continue(d) to preserve directors' discretion to act as mediators among all relevant corporate constituents." $" 135$ To make their point they analyzed two areas of corporate law where shareholders are privileged uniquely as compared to other constituencies affiliated with

132 The borrowing from the title of the 2006 climate change documentary "An Inconvenient Truth" is intentional.

133 Blair and Stout, supra note 1, 327.

$134 \quad$ Ibid., 287.

$135 \quad$ Ibid., 327. 
corporations, namely having standing to enforce breaches of duty by directors by way of a derivative suit and having the right to vote on prescribed key issues such as the election of directors. $^{136}$

With derivative suits, Blair and Stout pointed out that even if formally only shareholders can launch derivative suits the purpose of such proceedings is to enforce duties owed to the corporation rather than duties owed to shareholders and stressed that due to the business judgment rule directors have wide discretion available to manage a corporation as they see fit. ${ }^{137}$ This led them to argue that, contrary to what shareholder primacy implies, "Shareholders in public corporations can sue successfully in the firm's name only in situations where bringing suit benefits not only the shareholders, but the other stakeholders in the coalition as well." 138 With shareholder voting rights Blair and Stout conceded in their 1999 article that rights shareholders had to select directors and vote on certain fundamental corporate changes seemed "to grant shareholders a much greater measure of control over how the firm is run than other members of the coalition enjoy."139 Citing the fact that "legal and practical obstacles to shareholder action render voting rights almost meaningless" Blair and Stout countered by saying that the right to vote on corporate changes was a "fig leaf" and "that shareholders in public corporations do not in any realistic sense elect boards. Rather boards elect themselves." 140

Blair and Stout reviewed corporate law doctrine again in the 2006 article that was part of the symposium focusing on Robert Clark's corporate law treatise, citing various "anomalies" to indicate how "corporate law departs from the predictions of the principal-

\begin{tabular}{ll}
\hline 136 & Ibid., 288-89. \\
137 & Ibid., 292-309. \\
138 & Ibid., 309. \\
139 & Ibid., 310. \\
140 & Ibid., 311 (emphasis in original).
\end{tabular}


agent model". ${ }^{141}$ By this point they were by no means alone in casting doubt upon shareholder primacy as legal doctrine. Eric Talley said in 2002 "that much of corporate law has already rejected shareholder primacy arguments in favor of allowing managers greater freedom of action." 142 In the same symposium issue that Blair and Stout's 2006 article was a part of Jill Fisch observed that "Commentators widely recognize that shareholder primacy functions more as a norm than an enforceable legal rule."143 Martin Gelter suggested in a 2013 paper that was part of the proceedings of the fourth Berle symposium that U.S.

corporate law "reflect(ed) the managerialist world." 144 Jonathan Macey said in his review of The Shareholder Value Myth that "shareholder primacy...is not law at all... and nobody thinks that it is."

The post-1999 challenge to shareholder primacy extended beyond corporate law doctrine. Blair and Stout noted in their 2006 article that "corporate scholars are involved in an escalating debate over the best way to understand the modern corporation" $" 146$ but the trend was by no means restricted to corporate law academics. An intellectual assault on shareholder primacy began in earnest with the drop in share prices occurring when the “dot.com" stock market boom ended in 2000. ${ }^{147}$ Lisa Fairfax said in her 2006 Clark treatise symposium paper that "Since 2000, corporate disclosure reflects a shift from the traditional

\footnotetext{
$141 \quad$ Blair and Stout, supra note 5, 743.

142 Eric Talley, On the Demise of Shareholder Primacy (Or, Murder on the James Trains Express), 75 So. CAL. L. REV. 1211, 1213 (2002).

$143 \quad$ Jill E. Fisch, Measuring Efficiency in Corporate Law: The Role of Shareholder Primacy, 31 J. CORP. L. 637, 650 (2006).

144 Martin Gelter, The Pension System and the Rise of Shareholder Primacy, 36 SEATTLE UNIV. L. REV. 909, 920 (2013).

$145 \quad$ Macey, supra note 126, 911.

$146 \quad$ Blair and Stout, supra note 5, 743.

147 Justin Fox, How Shareholders Are Ruining American Business, ATLANTIC MonTHLY, July 2013.
} 
shareholder rubric to an embrace of rhetoric focused on stakeholders."148 To illustrate her point, she quoted a 2005 Economist survey on corporate social responsibility that argued this movement had "won the battle for ideas", meaning it was difficult to find a big company that would justify its existence purely in terms of profit. ${ }^{149}$

The financial crisis put the shareholder value norm under further pressure. ${ }^{150}$ A 2009 editorial in the Financial Times suggested "A palace revolution in the realm of business is toppling the dictatorship of shareholder value maximisation as the sole guiding principle for corporate action." 151 Indeed, as Stout observed in The Shareholder Value Myth, "Even former champions of shareholder primacy (were) beginning to rethink the wisdom of chasing shareholder value." ${ }^{\prime 152}$ She cited the example of Jack Welch, former chief executive of General Electric and an early advocate of shareholder value maximization, who said in a 2009 Financial Times interview "shareholder value is the dumbest idea in the world."153 Similarly, Michael Jensen, co-author of a foundational article on principal/agent theory, ${ }^{154}$

148 Lisa M. Fairfax, The Rhetoric of Corporate Law: The Impact of Stakeholder Rhetoric on Corporate Norms, 31 J. CORP. L. 675, 691 (2006).

149 Ibid:; The Good Company: A Survey of Corporate Social Responsibility, ECONOMIST, Jan. 22, 2005, 3.

150 Justin Baer, Francesco Guerrera and Richard Milne, A Need to Reconnect, FIN. TIMES (Asia ed.), March 13, 2009, 9 ("Long-held tenets of corporate faith - the pursuit of shareholder value... - are being blamed for the turmoil and look likely to be overhauled"); $A$ New Idolatry, ECONOMIST, April 24, 2010, 65 (saying the shareholder value norm "was spreading rapidly around the world until the financial crisis hit, calling its wisdom into question").

151 Shareholder Value Re-evaluated, FIN. TIMES, March 16, 2009, 12.

152 STOUT, supra note 5, 5.

153 Ibid., 5-6; Francesco Guerrera, Welch Denounces Corporate Obsessions, FIN. TIMES (U.S. ed.), March 16, 2009, 1.

154 Jensen and Meckling, supra note 62. 
said "I have never said - and if I have I was being stupid - that a company should be run for its stockholders."

Stout's The Shareholder Value Myth and similar views expressed by other academics prompted New York Times columnist Joe Nocera, to say in 2012 that "it feels as if we are at the dawn of a new movement - one aimed at overturning the hegemony of shareholder value." 156 It might seem, then, that the intellectual ferment qualifies in Kuhnian terms as a sufficient accumulation of anomalies to provide the platform for a paradigm (or at least subparadigm) shift away from the shareholder primacy norm in favor of a (sub-)paradigm oriented around team production. It is far from clear, however, that matters have reached this stage. Nocera, for example, substantially hedged his bets, saying of the challenge to shareholder primacy "it is hard to know yet whether this new movement will have legs" and observing "shareholder value is so deeply entrenched, it will be difficult to dislodge."157

The shareholder value norm certainly continues to have its defenders. For instance, even though Macey said in his review of The Shareholder Myth that he believed the shareholder primacy norm was an "illusion" in the sense that executives were neither bound by law to promote shareholder value nor were genuinely convinced they should act in this manner, he maintained shareholder primacy served a valuable governance function as a benchmark for identifying self-serving managerial conduct. ${ }^{158}$ There is a more prosaic

\footnotetext{
155 Quoted in Terence Corcoran, A CEO Fix We Do Not Need, NATIONAL Post, Jan. 8, 2012.

156 Joe Nocera, Down With Shareholder Value, N.Y. TIMES, Aug. 10, 2012, 19.

157 Ibid.

158 Macey, supra note 126, 911-12, 916, 924. For other examples, see New Idolatry, supra note 150 (arguing that the shareholder value model should not be replaced but deployed more effectively); Shareholder Value (Lex Column), Fin. TIMES, February 4, 2009 ("...while the theory of shareholder value is down, it is not out. There is no intellectually coherent alternative")' Russ Banham, Accountable to Whom? A Defense of Shareholder Primacy, CFO, Nov. 2012, 54 (citing views of Charles Elson).
} 
reason, however, why it is unlikely that the decks will be cleared soon in a way that provides the platform for the intellectual dominance of a team production model presupposing boards will act as the neutral arbiters and mediating hierarchs. This is the growing prominence of hedge fund activism.

\section{B. The Prominence of Hedge Fund Activism}

In the 2000s a sub-set of hedge funds -- collective investment vehicles structured to operate outside the scope of the Securities and Exchange Commission's regulation of investment companies (i.e. mutual funds) -- stepped forward in earnest as activist investors targeting underperforming companies. ${ }^{159}$ The typical tactic of an activist hedge fund was to build up quietly a sizeable strategic holding in a public company those running the hedge fund believed was failing to maximize shareholder returns and then agitate for change to correct matters. ${ }^{160}$ Common demands were for targeted companies to return cash to shareholders by way of a stock buyback or a one-off dividend payment, to sell weak divisions to improve the bottom line or even to put the company itself up for sale. ${ }^{161}$

By the mid-2000s it was clear hedge fund activism was a potentially significant corporate governance phenomenon. ${ }^{162}$ The financial crisis sideswiped activist funds but they rallied quickly. ${ }^{163}$ They subsequently went from strength to strength, launching campaigns at more than one-fifth of companies in the S\&P 500 between 2009 and $2014 .^{164}$ In 2012, the Wall Street Journal suggested that the acquisition of a $\$ 2$ billion stake in Proctor \& Gamble

159 Brian R. Cheffins and John Armour, The Past, Present, and Future of Shareholder Activism by Hedge Funds, 37 J. CORP. L. 51, 75, 80-82 (2011).

$160 \quad$ Ibid., 57-59.

161 Ibid., 60-61.

$162 \quad$ Ibid., 53.

163 Ibid., 53.

164 The Barbarians Return to the Gate, FIN. TIMES, April 25, 2014, 10 (citing data from FactSet Research Systems). 
Co. by Pershing Square Capital Management, a leading activist hedge fund William Ackman runs, reflected "a new era of activist investing" and meant "even America's largest corporations need to keep an eye out for investors who might push for board seats and big shifts in strategy."165 The Financial Times said 2013 marked "the triumph of activism" and Barron's observed the same year that "(a)ctivist investing ha(d) entered a new golden age.",166 In 2014, the New York Times said of Daniel Loeb's Third Point LLC, another major activist hedge fund, and its brethren, "They have amassed huge war chests to take on some of the biggest names in corporate America - and win more often than not."167

The success activist hedge funds have had obtaining representation on boards illustrates their growing influence. While when Blair and Stout wrote their 1999 article on team production boards may well have in effect elected themselves, ${ }^{168}$ hedge funds can now have a substantial say when they target companies. According to FactSet Research $60 \%$ of proxy fights prompted by a hedge fund activist that went to an actual vote in 2013 resulted in at least a partial activist victory, the highest win rate in the thirteen years the firm had been tracking the data. ${ }^{169}$ Though hedge fund activists only obtained directorships at 18 U.S. public companies in 2013 when a vote occurred, on 72 additional occasions they secured board seats in settlements reached after launching a proxy contest. ${ }^{170}$ Moreover, in a

165 Scott Thurm and David Benoit, Activists Go After Big Game, WALL St. J., July 16, 2012, B1.

166 Stephen Foley, The Brave New World of Investor Activism, FIN. TIMES (U.S. edition), Dec. 24, 2013, 15; Avi Salzman, How to Profit From Today's Shareholder Activism, BARRON's, Nov. 30, 2013, 25.

167 Michael J. de la Merced and Alexandra Stevenson, Sotheby's Yields to Hedge Fund Mogul and Allies, N.Y. Times, May 6, 2014, B1.

168 Supra note 140 and related discussion.

169 FactSet Research, Activists Increasing Success Gaining Board Seats at US Companies, http://www.factset.com/insight/2014/3/sharkspotlight_3.11.14 (accessed May 14, 2014).

$170 \quad$ Ibid. 
departure from past practice public companies have begun offering, as a means of forestalling prolonged confrontation, boardroom representation to activists who have not even launched proxy contests for board seats. ${ }^{171}$ Carl Icahn, a veteran shareholder activist, remarked in 2013 he was "surprised" how readily board seats were being offered without a proxy fight. ${ }^{172}$

The success of hedge fund activists has in turn influenced the boardroom agenda. The Financial Times indicated in 2013 that activists were finding "more directors receptive to the traditional activist ideas of returning capital, spinning off businesses and even inviting activists' representatives on to the board."173 Similarly according to Barron's "companies under scrutiny see little choice but to unbolt their boardroom doors." ${ }^{\prime 14}$ Companies, moreover, are not waiting until they have been targeted to introduce changes hedge funds would view favorably. In 2013 the New York Times quoted the head of contested situations at a major investment bank as saying "Your defense today before an activist shows up is all about blocking and tackling, dynamic self-assessment, followed by really enhanced investor outreach."175 In other words, those running public companies "look at (their) company through the lens of an activist." ${ }^{\prime 16}$ Moody's, the bond-rating agency, identified a potential by-product in a 2014 report to clients, suggesting that bondholders could face "a rising tide of

$171 \quad$ Ibid.; David Benoit, Companies, Activists Declare Truce in Boardroom Battles, WALL ST. J., Dec. 10, 2013, A1.

$172 \quad$ Ibid.

$173 \quad$ Foley, supra note 166.

174 Salzman, How to, supra note 166.

175 David Gelles, Boardrooms Rethink Tactics to Defang Activist Investors, N.Y. TIMES, Nov. 12, 2013, F10 (quoting Chris Young of Credit Suisse).

176 Dan McCrum and David Gelles, Stirrers and Shakers, Fin. TIMES, August 22, 2012, 7 (again quoting Chris Young of Credit Suisse). 
credit negative events" as managers apprehensive about hedge fund activism took action to distribute cash to shareholders that jeopardized cost-saving initiatives. ${ }^{177}$

Activist hedge funds are not having matters entirely their own way with public companies. Instead, a growing number of boards are changing corporate by-laws to introduce a new generation of poison pills - mechanisms designed to preclude an unwanted shareholder from acquiring a stake above a prescribed level -- that kick into operation at considerably lower thresholds (typically around 10\%) to bolster leverage in dealings with activist investors. ${ }^{178}$ Implicitly confirming Blair and Stout's observation that courts afford boards wide discretion to run corporations in the manner directors see fit the Delaware Court of Chancery upheld in a 2014 case the validity of a poison pill of auction house Sotheby's that impinged upon Daniel Loeb's Third Point. ${ }^{179}$

Though the Delaware Court of Chancery's ruling would have been a disappointment to hedge fund activists, it seems unlikely to mean the end of "the new era of activist investing.” In Sotheby’s dispute with Third Point, despite Sotheby's courtroom victory, Sotheby's agreed to endorse Third Point's three nominees as directors, partly due to backing Institutional Shareholder Services (ISS), an influential shareholder advisory firm, was providing for Third Point. ${ }^{180}$ So long as activist hedge funds can secure support from key players such as ISS they will continue to have considerable clout in the boardroom. For instance, due to opposition from ISS in 2014 most of 33 public companies that had adopted

177 Stephen Foley, Activist Funds Raise Corporate Bond Risk, Says Moody's, Fin. TIMES, March 11, 2014, 30; David Benoit and Gillian Tan, Bondholders in Activists' Crossfire, WaLl ST. J., March 11, 2014, C3.

178 Liz Hoffman, Bitter Medicine in Store for Activists, WALL ST. J., January 29, 2014, C1; Liz Hoffman, "Poison Pill” Gets a Bit More Toxic, Wall St. J., May 8, 2014, C1. 179 Third Point LLC v. Ruprecht, C.A. No. 9469-VCP, memo. op. (Del. Ch. May 2, 2014).

180 Steven M. Davidoff, A Truce at Sotheby's After a Costly and Avoidable Battle, N.Y. Times, May 6, 2014, B5. 
by-laws precluding directors nominated by activist shareholders from taking payment from the activist reversed course. ${ }^{181}$ The upshot is that even if shareholder primacy has suffered setbacks in the battle of ideas over the past few years, to the extent that directors might be inclined to act as mediating hierarchs rather than focus on shareholder value, hedge fund activism's "triumph" means they will pause. That is potentially an inconvenient truth for team production theory.

\section{Blair, Stout and Hedge Fund Activism}

Blair and Stout did not refer to hedge funds or shareholder activists in the 1999 article where they introduced the team production model. ${ }^{182}$ This is hardly surprising. While some hedge fund activism did occur in the 1990s, it was not at that point a significant corporate governance phenomenon. ${ }^{183}$

Blair and Stout did briefly acknowledge in their 1999 article the growth in prominence of mainstream institutional shareholders -- mutual funds and pension funds -saying that a 1980s move to the forefront by institutional investors might explain why boards, as mediating hierarchs, had been directing to shareholders an increasing proportion of the surplus corporate team production generated. ${ }^{184}$ Substantial growth in institutional ownership as a percentage of publicly traded shares may indeed help to explain why shareholder primacy achieved prominence as the $20^{\text {th }}$ century drew to a close. ${ }^{185}$ Still, while the rise of institutional shareholders prompted predictions in the early 1990s that meaningful shareholder control of public companies could be on the cards such expectations were largely

\footnotetext{
181 Stephen Foley, Battle for the Boardroom, FIN. TIMES, April 24, 2014, 9.

182 The phrase "shareholder activism" does appear once in the article but as part of the title of an article cited -- Blair and Stout, supra note 1, 311, n. 170.

183 Cheffins and Armour, supra note 159, 79-81.

184 Blair and Stout, supra note 1, 325-26.

185 Gordon, supra note 50, 1528-29.
} 
unfulfilled. ${ }^{186}$ For instance, John Bogle, founder of the Vanguard mutual fund group, remarked in 2007 upon "the virtual absence of mutual funds and private pension funds from actual participation in corporate governance." 187 Correspondingly, it is understandable that when Blair and Stout initially presented their team production model they did not treat shareholder activism as a major stumbling block for directors seeking to operate as mediating hierarchs rather than merely as agents for shareholders.

What have Blair and Stout had to say about the subsequent surge in hedge fund activism? To this point Margaret Blair has only referred to hedge funds very briefly in her writing and has not sought to address in any detail the implications of the "golden age" of hedge fund activism for the team production model or corporate law theory more generally. ${ }^{188}$ Lynn Stout has been more forthcoming. She has acknowledged, for instance, that the influence of hedge funds and shareholders more generally has been growing. In a 2008 article she and Iman Anabtawi co-wrote they said that "because of activist hedge funds, 'the balance of power is shifting away from boards.",189 Moreover, in a 2013 article in which Stout agreed with Ed Rock that U.S. corporate governance was a "shareholder-centric" system she acknowledged the "increasing clout" of hedge funds together with mainstream

186 Cheffins, supra note 30, xix-xx; Stephen M. Bainbridge, The Case for Limited Shareholder Voting Rights, 53 UCLA L. REV. 601, 628-30 (2006).

187 John C. Bogle, Democracy in Corporate America, DǢDAULs, Summer 2007, 24, 31.

188 In a chapter in a research handbook on corporate law Blair cited empirical research indicating that hedge fund activism can have an adverse impact on bondholders: Blair, supra note 83, 46. Otherwise, it does not appear that Blair has written about activist hedge funds. An April 2014 Westlaw search of law reviews using the search term "hedge fund" and stipulating that "Blair" be the author yielded no "hits". Running the same author search in conjunction with the search term "shareholder primacy" yielded one post-mid-2000s hit, a 2013 article in which Blair mentioned the term once in a footnote: Margaret M. Blair, Corporate Personhood and the Corporate Persona, [2013] U. ILL. L. REV. 785, 820, n. 194. 189 Iman Anabtawi and Lynn Stout, Fiduciary Duties for Activist Shareholders, 60 STANFORD L. REV. 1255, 1279 (2008). The quote they relied upon was from Banc of America Securities' head of global mergers and acquisitions. 
investors and indicated that "shifts in corporate law and practice over the past two decades" had "largely solved" the problem of "wayward managers exploiting helpless shareholders.",190

There is a potential clash between what Stout has said about shareholder activism trends and her prediction concerning team production model's emergence as a new corporate law paradigm. It is difficult to see how directors can act effectively as mediating hierarchs in the way team production theory requires in a milieu where hedge funds are fostering a shift of power in favor of shareholders in what has already, according to Stout, evolved into a shareholder-centric corporate governance system. Correspondingly, even if the shareholder primacy norm has been subjected to intellectual criticism, it hardly seems the decks are clear, or are likely to be soon, for the arrival of new corporate law (sub-)paradigm in which team production theory will be an integral element.

The inconvenient truth hedge fund activism poses for the team production model does not mean Stout is waving any white flags. Instead, in her symposium contribution for the fourth Berle symposium she said shareholder primacy had been "largely falsified" and asserted "it is time to move on to another theory", heralding in so doing "some form of managerial capitalism" as a contender. ${ }^{191}$ Why might a shareholder-centric system bolstered by hedge fund activism be on the ropes in the manner Stout implies? She went on to say in her contribution to the fourth Berle symposium that shareholder primacy was like Communism, in that both were theories that were "embraced for a period of time" but were "not firmly grounded in the realities of the world" and thus were "doomed to fail". 192

190 Lynn Stout, The Toxic Side Effects of Shareholder Primacy, 161 U. PENN. L. REV. 2003, 2009, 2019 (2013).

$191 \quad$ Stout, supra note $9,1181$.

192 Ibid., 1184. 
In what sense has shareholder primacy not been "firmly grounded"? Stout suggested that while shareholder primacy might be "elegant and intellectually appealing" it had failed to deliver beneficial results, not only for corporate constituencies other than shareholders but for shareholders themselves. ${ }^{193}$ How can it be that shareholder primacy has worked out badly for shareholders? Here hedge fund activists, characterized by Stout as investors who are "notorious" for owning shares for short periods, ${ }^{194}$ have been tagged as culprits. According to Stout, "the new shareholder-centric reality causes managers to think, in particular, like short-term shareholders", ${ }^{195}$ thereby prompting counterproductively myopic business decisions that erode shareholder returns over the long haul. ${ }^{196}$

Stout, in The Shareholder Value Myth, elaborated upon how the agenda of hedge fund activists differ from that of other shareholders. She contrasted "universal" owners (retail and institutional investors with stakes in the economy and the community other than shares in public companies), with hedge funds, which she said exercised disproportionate and counterproductive influence by "taking relatively large positions in relatively few companies...(to) position themselves with realistic threats of embarrassing news stories and proxy battles...."197 According to Stout, the interests of hedge fund activists and universal owners "often clash" as hedge funds pressure companies to make changes that bolster shareholder returns in the few companies in which they own stock while the interests of diversified universal owners are prejudiced because the changes prompt the value of bonds

\footnotetext{
$193 \quad$ Ibid., 1181; Stout, supra note 190, 2023.

194 Stout, supra note 190, 2017.

195 Ibid., 2019.

$196 \quad$ Ibid., 2017.

$197 \quad$ STOUT, supra note 5, 94.
} 
and other shares the universal owners hold to decline and cause employee benefits such as pensions to be cut. ${ }^{198}$

The dynamics of share ownership in publicly traded companies cast doubt on Stout's argument that the interests of hedge fund activists and mainstream institutional shareholders key examples of her "universal owners" - are destined to clash. If disagreements between hedge fund activists and mainstream institutional investors were fundamental and commonplace, hedge fund activism would be a much less prevalent and influential strategy than it is currently. Hedge fund activists acquire, on average, ownership stakes of $8 \%$ in the public companies they target. ${ }^{199}$ Under such circumstances hedge fund activists will only have significant leverage over the directors of the companies they target if they can persuade a substantial proportion of other shareholders to support the initiatives they propose. ${ }^{200}$ As William Ackman, the prominent hedge fund activist, has said:

"The vast majority of capital in the world is passive. These investors control the votes. If they think an activist is wrong, they won't support him. But at least they have a choice.",201

Given the choice shareholders have concerning hedge fund activist initiatives, as Ronald Gilson and Jeffrey Gordon have observed, with U.S. public companies "both activist and

$198 \quad$ Ibid., 92.

199 Ronald Gilson and Jeffrey Gordon, The Agency Costs of Agency Capitalism: Activist Investors and Revaluation of Governance Rights, 113 COLUM L. REV. 863, 899 (2013).

$200 \quad$ Cheffins and Armour, supra note 159, 67; Robert C. Pozen, The Misdirected War on Corporate Short-Termism, WALl ST. J., May 20, 2014, A11.

201 Quoted in Francesco Guerrera, Activist Investors - A Roar or a Bark?, W ALL ST. J., August 20, 2013, C1. See also Stephen Foley, Hedge Funds Launch Bonus Fight, Fin. TIMES, Dec. 30, 2013, 15 (quoting a partner at Jana Partners, an activist hedge fund, as saying "Our only real constituency is shareholders. If we can convince them we have a structure that works then we can get there.") 
institutional shareholders must agree for a proposal to go forward."202 Due to this "happy complementarity"203 a direct clash of interests between hedge fund activists and other shareholders should be the exception to the rule. ${ }^{204}$

Mainstream institutional shareholders began offering backing for hedge fund activists with regularity in the early 2000 s, which set the stage for hedge funds to move to emerge as meaningful governance players. ${ }^{205}$ The "happy complementarity" between hedge fund activists and institutional shareholders seems to be growing in strength, which in turn has helped to foster the post-financial crisis surge in activism. ${ }^{206}$ In 2013 Mary Jo White, the Securities and Exchange Commission chairman, indicated that while "the 'activist' moniker had a distinctly negative connotation" there was now "widespread acceptance of many of the policy changes that so-called 'activists' are seeking to effect." ${ }^{207}$ Indeed, U.S. pension funds

202 Gilson and Gordon, supra note 199, 897; see also Andrew Ross Sorkin, For Activist Shareholders, A Wide Reporting Window, N.Y. TIMES, May 19, 2014, B1 (saying of hedge fund activists "if the rest of the shareholders do not agree with you, you're toast").

203 Gilson and Gordon, supra note 199, 898. See also David Gelles and Michael J. de la Merced, New Alliances in Battle for Corporate Control, N.Y. TIMES, March 19, 2014, B1 (referring to "collaboration").

204 Cheffins and Armour, supra note 159, 67; George W. Dent, The Essential Unity of Shareholders and the Myth of Investor Short-Termism, 35 DEL. J. CORP. L. 97, 117 (2010) (saying it is not credible investors would have failed to catch on if hedge funds were promoting a short-term agenda at the expense of long-term returns, reasoning "Are the vast majority of investors idiots? Quite simply, the investing public perceives these situations not as a threat but a boon to share value.")

205 Cheffins and Armour, supra note 159, 87.

206 Alexandra Stevenson, No Barbarians at the Gate; Instead, a Force for Change, N.Y. TIMES, January 7, 2014, B1 (quoting William Ackman as saying "It used to be that boards of decent-sized companies were impenetrable. What's changed is that institutions are prepared to replace directors, including the chairman and chief executive in light of underperformance"); Adam Shell, Rich Activist Investors Go Gunning For Big Game, USA TODAY, Aug. 15, 2013, B1 (citing a shift in the attitude of institutional investors as an explanation for the new-found ability of hedge fund activists to target very large public companies).

207 Mary Jo White, Remarks at the 10th Annual Transatlantic Corporate Governance Dialogue (Dec. 3, 2013), available at http://www.sec.gov/News/Speech/Detail/Speech/1370540434901\#.U3XquBsU-Uk (accessed 
have begun investing directly in activist hedge funds and activist Carl Icahn has said that some mainstream institutional investors "even egg us on."208 Given such observations it not only is doubtful that the priorities of hedge fund activists and other shareholders diverge in the manner Stout has suggested but also that directors will be in a position any time soon where they can treat shareholders as just another corporate constituency to take into account in the boardroom. It correspondingly seems unlikely team production theory will displace shareholder primacy as a corporate governance paradigm (or sub-paradigm) in the foreseeable future.

\section{CONCLUSION}

Margaret Blair and Lynn Stout, in their path-breaking 1999 article “A Team Production Theory of Corporate Law" neither cited Thomas Kuhn nor referred to their team production model as a potential new corporate law paradigm. ${ }^{209}$ This is not surprising, given that they situated the model as an elaboration upon the then dominant mode of corporate law thinking, the nexus of contracts model. Correspondingly, it might seem that this paper, by evaluating the team production model by reference to Kuhn and his notions of scientific revolutions and paradigm shifts, engages in inappropriate benchmarking. Blair and Stout, however, did invoke Kuhn explicitly in a 2006 article on anomalies - another Kuhnian term affecting corporate law theory when arguing team production theory could be part of a new

May 16, 2014). See also Michael J. de la Merced and Julie Creswell, With Huge War Chests, Activist Investors Tackle Big Companies, N.Y. TIMES, Aug. 31, 2013, A1 ("Traditional mutual funds and asset managers have become more open in supporting activist campaigns as well, after years of shying away from the hedge funds as loudmouthed, bare-knuckled brawlers").

208 Let's Do it My Way, Economist, May 25, 2013, 79; see also Gelles and de la Merced, supra note 203 (quoting William Ackman as saying "Periodically, we are approached by large institutions who are disappointed with the performance of companies they are invested in to see if we would be interested in playing an active role in effectuating change").

209 The word "paradigm" was used once as part of the phrase "rational actor paradigm": Blair and Stout, supra note 1, 317, n. 183. 
corporate law paradigm. ${ }^{210}$ Correspondingly, for the purposes of this symposium on the team production model Kuhn and his work do provide an appropriate reference point for analyzing Blair and Stout's model.

This paper has shown that on various levels situating team production theory as a new corporate law paradigm is problematic. It is unclear whether Kuhnian concepts can be deployed appropriately with corporate law theory, given that the scientific method of enquiry of interest to Kuhn has not been routinely invoked by corporate law scholars and given that the intellectual consensus required for Kuhn's "normal science" to occur may have never been present in the corporate law realm. Even if corporate law scholarship trends are reducible to Kuhnian terms team production theory's status as a new paradigm is questionable. Not only did Blair and Stout fail to challenge directly in their path-breaking 1999 article the dominant contractarian paradigm but their characterization of boards under team production resembles in various ways managerialist thinking associated with the separation of ownership and control paradigm that preceded the intellectual dominance of the nexus of contracts model.

It is true that Blair and Stout did challenge directly in their 1999 article a shareholder primacy norm often linked with the nexus of contracts model that could perhaps be characterized as a sub-paradigm of corporate law scholarship. In so doing, they made various telling points concerning corporate law doctrine. Nevertheless, subsequent events indicate that shareholder primacy may well be resilient in the corporate governance realm despite a strong intellectual challenge Blair and Stout and others posed. In particular, a surge in hedge fund activism surge occurring over the past decade has meant that directors of public corporations have had to treat shareholders as a priority in a way that team production theory does not countenance.

$210 \quad$ Blair and Stout, supra note 5. See supra note 19 and related discussion. 
While this paper has shown team production theory is unlikely to achieve paradigmatic status within the realm of corporate law theory, this does not detract materially from the contribution that Blair and Stout's 1999 article has made to corporate law scholarship. Academic work that qualifies as the foundation for a new paradigm is exceedingly rare, even assuming that an intellectual discipline is suited for analysis in Kuhnian terms. Team production theory seems unlikely to become part of such rarefied company. Nevertheless, Blair and Stout's 1999 article has been widely read and cited and has prompted considerable debate among legal academics and more broadly, with this $6^{\text {th }}$ Berle symposium being merely the most recent evidence of the article's substantial impact. Invoking Kuhn one last time, not bad for normal science! 